\title{
Multisociety (AATS, ACCF, SCAI, and STS) expert consensus statement: Operator and institutional requirements for transcatheter valve repair and replacement, part 1: Transcatheter aortic valve replacement
}

\author{
Carl L. Tommaso, MD, ${ }^{\mathrm{a}}$ R. Morton Bolman III, MD, ${ }^{\mathrm{b}}$ Ted Feldman, MD,${ }^{\mathrm{c}}$ Joseph Bavaria, MD ${ }^{\mathrm{d}}$ \\ Michael A. Acker, MD, ${ }^{\mathrm{d}}$ Gabriel Aldea, MD,${ }^{\mathrm{e}}$ Duke E. Cameron, MD, ${ }^{\mathrm{f}}$ Larry S. Dean, MD, ${ }^{\mathrm{e}}$ \\ Dave Fullerton, MD, ${ }^{\mathrm{g}}$ Ziyad M. Hijazi, MD, ${ }^{\mathrm{h}}$ Eric Horlick, MD, ${ }^{\mathrm{i}}$ D. Craig Miller, MD, ${ }^{\mathrm{j}}$ \\ Marc R. Moon, MD, ${ }^{\mathrm{k}}$ Richard Ringel, $\mathrm{MD},{ }^{\mathrm{f}}$ Carlos E. Ruiz, MD, PhD, ${ }^{1}$ Alfredo Trento, MD, ${ }^{\mathrm{m}}$ \\ Bonnie H. Weiner, MD, ${ }^{\mathrm{n}}$ and Evan M. Zahn, $\mathrm{MD}^{\mathrm{O}}$
}

f Supplemental material is available online.

\section{PREAMBLE}

The granting of staff privileges to physicians is an important mechanism to ensure quality care. The Joint Commission on Accreditation of Healthcare Organizations requires that medical staff privileges be based on professional criteria specified in medical staff bylaws. Physicians are charged with defining the criteria that constitute professional competence and with evaluating their peers accordingly. With the evolution of transcatheter aortic valve replacement (TAVR), an important opportunity arises for both cardiologists and surgeons to come together to identify the criteria for performing these procedures. The Society for Cardiovascular Angiography and Interventions (SCAI), American Association for Thoracic Surgery (AATS), American College of Cardiology Foundation (ACCF), and the Society of Thoracic Surgeons (STS) have, therefore, joined together to provide recommendations for institutions to assess their potential for instituting and/or maintaining a transcatheter valve program. This article concerns TAVR. As TAVR is in its infancy, there are few data on which to base this consensus statement. Therefore, many of these recommendations are based on expert consensus. As the procedures

\footnotetext{
From the Division of Cardiology, ${ }^{\mathrm{a}}$ NorthShore University HealthSystem, Skokie

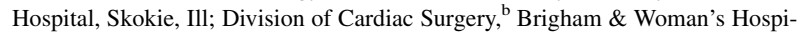
tal, Boston, Mass; Division of Cardiology, ${ }^{\mathrm{c}}$ NorthShore University HealthSystem, Evanston Hospital, Evanston, Ill; Division of Cardiothoracic Surgery, ${ }^{\mathrm{d}}$ University of Pennsylvania Medical Center, Philadelphia, Pa; Division of Cardiothoracic Surgery, ${ }^{\mathrm{e}}$ University of Washington Medical Center, Seattle, Wash; Division of Cardiothoracic Surgery, ${ }^{\mathrm{f}}$ The Johns Hopkins Hospital, Baltimore, Md; Division of Cardiothoracic Surgery, ${ }^{\mathrm{g}}$ University of Colorado, Aurora, Colo; Division of Pediatric Cardiology, ${ }^{\text {h }}$ Rush University Medical Center, Chicago, Ill; Division of Cardiology, ${ }^{\mathrm{i}}$ Toronto General Hospital, Toronto, Ontario, Canada; Division of Cardiovascular Surgery, ${ }^{\mathrm{j}}$ Stanford University Medical Center, Stanford, Calif; Division of Cardiothoracic Surgery, ${ }^{\mathrm{k}}$ Washington University, St. Louis, Mo; Lenox Hill Heart and Vascular Institute of New York, ${ }^{1}$ New York, NY; Division of Cardiothoracic Surgery, ${ }^{\mathrm{m}}$ Cedar Sinai Medical Center, Los Angeles, Calif;
}

evolve, technology changes, experience grows, and more data is accumulated, there will certainly be a need to update this consensus statement. However, with the Food and Drug Administration (FDA) having just approved the first generation of TAVR devices, the writing committee and participating societies believe that the recommendations listed in this report serve as an appropriate starting point. In some ways, these recommendations apply to institutions more than to individuals. As there is a strong consensus that these new valve therapies are best performed using a team approach, these credentialing criteria may be best applied at the institutional level. Partnering societies used the ACCF's policy on relationships with industry and other entities (RWI) to author this document (http:// www.cardiosource.org/Science-And-Quality/PracticeGuidelines-and-Quality-Standards/Relationships-WithIndustry-Policy.aspx). To avoid actual, potential, or perceived conflicts of interest that may arise as a result of industry relationships or personal interests among the writing committee, all members of the writing committee, as well as peer reviewers of the document, were asked to disclose all current health care-related relationships, including those existing 12 months before initiation of the writing effort. A committee of interventional cardiologists and surgeons was formed to include a majority of members with no relevant RWI, and be led by an interventional cardiology co-chair and a surgical co-chair with no relevant RWI. Authors

\footnotetext{
Saint Vincent Hospital at Worcester Medical Center, ${ }^{\mathrm{n}}$ Harvard, Mass; Division of Pediatric Cardiology, ${ }^{\circ}$ Miami Children's Hospital, Miami, Fla. Disclosures: See Appendices E1 and E2.

This article is copublished in The Journal of Thoracic and Cardiovascular Surgery, The Annals of Thoracic Surgery, The Journal of the American College of Cardiology, and Catheterization and Cardiovascular Interventions.

Address for reprints: Carl L. Tommaso, MD, Cardiac Catheterization Laboratory, NorthShore University HealthSystem Skokie Hospital, 9669 N Kenton Avenue, Skokie, IL 60076 (E-mail: ctommaso@northshore.org).

J Thorac Cardiovasc Surg 2012;143:1254-63

$0022-5223 / \$ 36.00$

Copyright (c) 2012 by The American Association for Thoracic Surgery, The Society of Thoracic Surgeons, the American College of Cardiology Foundation, and Society for Cardiovascular Angiography and Interventions.

doi:10.1016/j.jtcvs.2012.03.002
} 
with relevant RWI were not permitted to draft or vote on text or recommendations pertaining to their RWI. RWI were reviewed on all conference calls and updated as changes occurred. Author and peer reviewer RWI pertinent to this document are disclosed in Appendices E1 and E2, respectively. In addition, to ensure complete transparency, authors' comprehensive disclosure information (including RWI not pertinent to this document) is available as an online supplement to this document. The work of the writing committee was supported exclusively by the partnering societies without commercial support. Writing committee members volunteered their time to this effort. Conference calls of the writing committee were confidential and attended only by committee members. SCAI, AATS, ACCF, and STS believe that adherence to these recommendations will maximize the chances that these therapies will become a successful part of the armamentarium for treating valvular heart disease in the United States. In addition, these recommendations will hopefully facilitate optimum quality during the delivery of this therapy, which will be important to the development and successful implementation of future, less invasive approaches to structural heart disease.

\section{INTRODUCTION}

Enabled by the development of new technologies, treatment of valvular heart disease by transcatheter techniques is becoming a favored approach of cardiac providers, resulting in less invasive treatment for patients previously treatable only with open heart surgery or, in many cases, not treatable at all. Recognition from the medical community of the applicability, effectiveness, and practicality of catheter-based transcatheter valve therapies has further increased interest in these treatments. Training program content, standards, credentialing, and board certifications for cardiac surgical procedures and percutaneous coronary intervention (PCI) are well developed, but no such structure exists in the field of percutaneous structural or valvular heart disease therapies. The purpose of this article is to outline criteria for operator and institutional requirements to enable institutions and providers to participate responsibly in this new and rapidly developing field.

The emergence of transcatheter aortic valve repair and implantation as an alternative to traditional surgical therapy for valvular diseases has been facilitated by innovative devices, rapidly developing techniques, and careful patient selection. ${ }^{1}$ The combination of interventional skills, equipment, collaborative clinical management, surgical approaches, techniques, and decision-making distinguish the qualifications to participate in this field as unique, as does the complexity of the patients requiring these therapies. ${ }^{1-3}$ Given both the high-risk nature of these catheter interventions and the availability of established alternative treatment options using traditional surgical approaches, several considerations are important for institutions and operators planning to implement these new technologies.

Defining operator and institutional requirements for these novel therapies is an important first step in ensuring their optimal implementation.

Establishing a structural heart disease intervention therapy program requires several key components (Tables 1 and 2). The defining principle is that this effort is a joint, institutionally-based activity for cardiologists and cardiac surgeons. ${ }^{1,4}$ Thus, the specialty that provides some of these components will vary from program to program. A transcatheter aortic valve replacement (TAVR) program that uses only 1 specialty is fundamentally deficient, and valve therapy programs should not be established without this multidisciplinary partnership. Comprehensive multidisciplinary teams (MDTs) are, therefore, required for transcatheter valve therapies.

\section{KNOWLEDGE BASE AND SKILLS}

The critical cornerstone for establishing a transcatheter valve program is the formal collaborative effort between interventional cardiologists and cardiac surgeons. This element is essential for establishing a transcatheter valve program. No one individual, group, or specialty possesses all the necessary skills for best patient outcomes. ${ }^{1,5}$ The over-arching goal of these programs must be to provide the best possible patient-centered care. ${ }^{1,6}$

As these are new techniques, the correlation between operator experience and performance metrics for these procedures has yet to be established. The current pool of trained individuals is comprised predominantly of those who have participated in industry-sponsored trials aimed at device approval. Therefore, the translation of currently available experiences with transcatheter valve therapies to the "real world" has yet to be evaluated in the United States.

Several core concepts should be implemented for all physicians performing these procedures, irrespective of their specialty background. ${ }^{7,8}$ They should all possess extensive knowledge of valvular heart disease, including the natural history of the disease, hemodynamics, appropriate diagnostics, optimal medical therapy, application and outcome of invasive therapies, and procedural and perioperative care. ${ }^{9}$

The ability to interpret echocardiographic and other radiographic images (obtained at baseline, during the procedure, and follow-up) is critically important. MDTs and procedural teams need to possess echocardiographic interpretation skills for transthoracic and transesophageal studies. The use of 3-dimensional (3D) and 4-dimensional echoes may evolve to become essential diagnostic tools. Expertise in the interpretation of computed tomography (CT) scans of the iliofemoral vessels, cardiac anatomy, as well as aortic valvular anatomy, is critical for determining patient eligibility and the approach for procedures. ${ }^{8,10}$ 
TABLE 1. Transcatheter aortic valve replacement: Criteria for new and existing programs

New programs

Institutional interventional program

TAVR interventionalist

Institutional surgical program

TAVR surgeon

Existing programs Institutional

Training
100 Structural procedures lifetime or 30 left sided structural per year of which $60 \%$ should be balloon aortic valvuloplasty

(Left sided procedures include EVAR, TEVAR, BALLOON AORTIC VALVE [BAV], aortic valve $[\mathrm{AV}]$ and mitral valve $[\mathrm{MV}]$ prosthetic leak closures, and ventricular septal defect [VSD] closures.) (Atrial septal defect/patent foramen ovale [ASD/PFO] closure are not considered left sided procedures.)

Suitable training on devices to be used

50 Total AVR per year of which at least 10 aortic valve replacement (AVR) should be highrisk (STS score $\geq 6$ )

Minimum of 2 institutionally-based cardiac surgeons in program (more than $50 \%$ time at hospital with surgical program)

100 AVR career, at least 10 of which are "high-risk" (STS score $\geq 6$ ) or 25 AVR per year or 50 AVR in 2 years and at least 20 AVR in last year prior to TAVR initiation

Experience with, and management of, peripherally inserted cardiopulmonary bypass

Experience with open retroperitoneal exposure of, and surgical intervention on, the iliac arteries

Suitable training on devices to be used

Cardiologists must be board certified/eligible in interventional cardiology

Surgeons must be board certified/eligible in thoracic surgery

Additional operators who are trained or experienced in structural heart disease and have unrestricted hospital privileges in structural procedures may also be part of the interventional operating team with the interventional cardiologist and cardiovascular surgeon

Programs in existence $>18$ months: 30 TAVR (total experience)

Programs in existence $<18$ months: 2 per month

Cardiologists must be board certified/eligible in interventional cardiology

Surgeons must be board certified/eligible in thoracic surgery

Additional operators who are trained or experienced in structural heart disease, and have unrestricted hospital privileges in structural procedures, may also be part of the interventional operating team with the interventional cardiologist and cardiovascular surgeon

*With acceptable outcomes for conventional procedures compared to NCDR benchmarks.

As noted, there is as yet no demonstrated direct correlation between operator experience with specific procedures and the skills necessary to perform transcatheter valve procedures, although there are some procedures that require similar prerequisite skills such as balloon aortic valvuloplasty (BAV) for TAVR. There are, however, some core concepts that professional societies have accepted as important for both facilities and operators. ${ }^{1,11,12}$ Minimum training for specific procedures and devices will, for the immediate future, be primarily dictated by FDA approval requirements. Simulation is likely to play a significant role in technical training and proficiency maintenance for these evolving procedures. ${ }^{13-17}$ As these procedures become integrated into mainstream care delivery, the strategy for training will likely need to be revised.
Minimum requirements for transcatheter valve therapies include an understanding of basic radiation safety necessary for optimal imaging, operator and patient exposure protection, and knowledge of the use of X-ray contrast agents, which may not be standard in cardiac surgery training and experience.

Training in the use of closed systems for hemodynamic monitoring and contrast injections will result in optimal integration into catheterization laboratories and hybrid environments. Catheter and wire skills, including knowledge of the use of various techniques and the equipment available to access complex anatomy and negotiating necessary vascular and anatomic structures are required. Understanding of the interplay of wires, catheters, and anatomy is required for completion of these procedures. These skills can be acquired in a variety of ways. Prior experience with a variety 
TABLE 2. Volume and outcomes for continued certification for both new and existing TAVR programs applies to "inoperable" (PARTNER Cohort B) TAVR patients

Program volume of 20 TAVR per year or 40 per 2 years

30 -day all-cause mortality $<15 \%$

30-day all-cause neurologic events including transient ischemic attack

$$
\text { (TIAs) }<15 \%
$$

Major vascular complication $<15 \% *$

$>90 \%$ Institutional follow-up

$60 \%$ 1-year survival rate for nonoperable patients (cohort b) —after the program has been running for 2 years (2-year average)

Ongoing continuing medical education (CME) (or nursing/technologist equivalent) of $10 \mathrm{hr}$ per year of relevant material

All cases must be submitted to a single national database

*According to Valve Academic Research Consortium (VARC)-2 definitions. ${ }^{9 \mathrm{a}}$

of interventional techniques is important. These include but are not limited to:

- Coronary diagnostic procedures

- Coronary interventions

- Peripheral vascular diagnostic procedures

- Peripheral vascular interventions

- Balloon aortic, mitral, and pulmonic valve dilatation

- Stent implantation in right ventricle outflow tract and pulmonary arteries

- Intra-aortic balloon pump (IABP), other cardiac support device placement, including initiation of percutaneous cardiopulmonary bypass

- Percutaneous ventricular assist device placement

- Endovascular aneurysm repair (EVAR) or thoracic endovascular aortic repair (TEVAR) procedures

- Transseptal techniques

- Coronary sinus access

- Large vessel access and closure

Operators should also have experience with specific catheter-based techniques required for valve interventions. Similarly, surgeons should have experience with transapical approaches for left ventricular assist device placement and care of similar high-risk patients to perform transapical TAVR. ${ }^{11,12,18}$ The experience of an interventionalist or surgeon should be relevant to the transcatheter valve procedure undertaken. In this document, attention will focus on cardiac surgery and interventional cardiology experience relevant to aortic valve intervention.

The concept of sterile technique must be completely understood and stringently applied to the delivery of transcatheter valve therapies. Interventionalists must understand and be able to function in an environment that has more stringent sterile technique requirements than are common in catheterization laboratories. As one of the leaders of the team performing these procedures, the interventionalist must be able to enforce compliance with these standards. These procedures may involve open or partially open surgical components. Also, large devices that possess the same risk of infection as conventional valve prostheses will be implanted, especially for valve replacement procedures. Operating theater standards for sterile technique are, therefore, mandatory to ensure best patient outcomes.

\section{FACILITIES}

The institution should have an active valvular heart disease surgical program with at least 2 institutionally-based cardiac surgeons experienced in valvular surgery, and should contain a full range of diagnostic imaging and therapeutic facilities including:

1. Cardiac catheterization laboratory or hybrid operating room (OR)/cath lab equipped with a fixed radiographic imaging system with flat-panel fluoroscopy, offering catheterization laboratory quality imaging. A biplane unit may be advantageous, particularly for congenital heart disease.

2. Noninvasive imaging

a. Echocardiographic laboratory. Transthoracic and transesophageal echocardiographic capabilities with sonographers and echocardiographers experienced in valvular heart disease. Access to 3D echocardiography is preferable.

b. Vascular laboratory (noninvasive) with vascular specialists capable of performing and interpreting vascular studies.

c. CT laboratory with CT technologists and specialists who can acquire and interpret cardiac CT studies.

3. Physical space-The implantation suite must have a sterile environment that meets OR standards. Furthermore, it must have sufficient space to accommodate the necessary equipment for uncomplicated implantations as well as any additional equipment that may be necessary in the event of complications. This includes space for anesthesiology, echocardiography, and cardiopulmonary bypass equipment and personnel. A specifically designed hybrid OR interventional suite is ideal; however, in the absence of such a facility, the interventional cardiac suite should have:

a. Circulating heating, ventilation, and air conditioning laminar flow diffusers (providing smooth, undisturbed air flow and usually placed directly over the procedure table) to meet air requirements for surgery rooms.

b. Asymmetrical/symmetrical 6-lamp $2 \times 4$ troffers (the inverted, usually metal trough suspended from the ceiling as a fixture for fluorescent lighting) to provide adequate high-output lighting for surgical intervention.

c. Adequate number of power receptacles that meet surgical equipment requirements.

d. Capability of running cardiopulmonary bypass apparatus in the interventional suite. 
e. Gas outlets for the anesthesia machine.

f. Adequate room size to accommodate the standard equipment required in a cardiac catheterization laboratory (eg, high-definition displays and monitors, $\mathrm{O}_{2}$ analyzer, defibrillator/resuscitation cart, $\mathrm{O}_{2}$ supply, suction, compressed air, CO-oximeter, activated clotting time analyzer)

g. Minimum room size of 800 square feet $\left(74.3 \mathrm{~m}^{2}\right)$ to accommodate echocardiographic equipment, sonographers, anesthesia equipment, emergency CT surgical team and cardiopulmonary bypass equipment (eg, surgeon, assistant, scrub tech, pump techs), if needed.

4. Fungible equipment-The interventional suite should stock a large variety of fungible equipment, including various access kits, endovascular sheath and introducers ranging from 4 to $26 \mathrm{~F}$ in various lengths, a wide range of guide wires for various purposes, cardiac diagnostic and interventional catheters, vascular closure devices, balloon dilatation catheters ranging from 2 to $30 \mathrm{~mm}$ in diameter and of various lengths and profiles, bare metal and covered stents (eg, coronary and peripheral), occlusive vascular devices, snares and other retrieval devices, drainage catheters, and various implantable device sizes with their delivery systems.

5. Postprocedure intensive care facility with personnel experienced in managing patients who have undergone conventional open heart valve procedures.

6. Use of mobile C-arm imaging system in an OR is not adequate.

7. HYBRID OR - The "2012 American College of Cardiology Foundation Society for Cardiovascular Angiography and Interventions Expert Consensus Document on Cardiac Catheterization Laboratory Standards Update" will outline the specifications for a hybrid Cath Lab/ OR. ${ }^{18 a}$ Though this is preferable, it is not a prerequisite since it is not available at many institutions

Most importantly, there must be dedication on the part of the hospital to provide these services and support, both financially and with no time constraints on the personnel involved. A dedicated administrator as a member of the team is necessary.

\section{OTHER INSTITUTIONAL RESOURCES}

For preprocedure and postprocedure care and joint formal multidisciplinary patient consultation, adequate outpatient clinical care facilities are necessary. Appropriate office space for the medical, nursing, and technical personnel involved is also required, preferably in a central setting. Ancillary testing facilities (ie, pulmonary function, echocardiography, vascular Duplex scanning, clinical laboratory, multislice CT) should be of high quality and able to accommodate the patient load on a timely basis.

By their very nature, these complex procedures should only be performed in institutions that currently and routinely perform large volumes of surgical aortic valve operations with outcomes that equal or exceed those established nationally for similar procedures. Similarly, only institutions with interventional cardiology programs that have established and successful programs with BAV, catheter closure of periprosthetic valvular leaks, insertion of ventricular septal closure devices with outcomes that equal or exceed those established nationally for similar procedures should develop an integrated structural heart MDT.

The institutional commitment required for a successful program goes beyond the necessary space, personnel, and specialized facilities set forth above. The complex and time consuming preprocedure patient triage process and the amount and intensity of postprocedure patient care after discharge are very labor intensive for the physician and nursing staff, as are the informed consents and communications with patients, families, and referring providers. In addition to supporting the core nursing and technical support staff, arrangements between the institution and the physicians need to be structured to reimburse physician efforts dedicated to nonreimbursable hours of clinical care and medical management of the program.

The complexity of transcatheter valve procedures and the magnitude of institutional resources required are similar to established heart transplant and cardiac assist device programs, where dedicated professionals, a minimum of infrastructure, MDT, registered nurse/nurse practitioner (NP), providers, coordinators, databases, and quality reporting are essential for optimal patient outcomes. ${ }^{1}$ This concept was endorsed by the Centers for Medicare and Medicaid Services (CMS) through the establishment of certification criteria for the use of heart transplantation and cardiac assist devices in centers and, moreover, for eligibility for reimbursement of services provided. The same regulatory system was applied to professionals providing these services. Transcatheter valve treatment programs should undergo a similar regulatory process with CMS endorsement. Centers should be approved for transcatheter aortic valve programs based on a minimum number of cases per year, and perioperative and 1-year outcomes above a minimum threshold.

Long-term outcome reporting is obligatory, to track not only survival, but also other parameters including periprocedural complications (CVA, vascular, renal, infectious, etc), aortic regurgitation, the need for reintervention, subsequent surgery, and quality of life. This type of reporting is essential, since long-term outcome goals for these new procedures have not been established at this early stage. 
Participation in a national data registry (eg, STS/ACC TVT Registry) is mandatory. ${ }^{1}$

\section{MULTI-DISCIPLINARY TEAM}

The use of a team approach has been shown to improve outcomes in these types of complex procedures. ${ }^{19}$ The MDT necessary for a TAVR program is highlighted by the collaboration between the interventional cardiologist and cardiac surgeon. ${ }^{1}$ The MDT, however, goes well beyond this collaboration, and must include key providers from other physician groups (eg, anesthesiology, radiology, noninvasive cardiology, intensive care). In addition to the individual physicians, other components that extend to various departments are necessary. The idea that the MDT is comprised of individual physicians working in a room performing the procedures is a superficial view that does not take into account the level of resources necessary for a successful valve therapy program. The interaction among specialists in the MDT is fundamental, particularly for preprocedure patient evaluation and selection. It is equally fundamental that the patient be at the very center of all discussions and decision-making regarding the best therapy in her/his particular circumstance. While there is great excitement about the application of transcatheter valve therapies, most of these therapies will only be indicated for a small portion of the population for the immediate future. Proper decision-making and determination of best options for any given patient require an evaluation by the MDT. ${ }^{20}$

On-site valve surgery is an essential component of any valve therapy program. The requirement for on-site valve surgery is based not only on the potential need for emergency or "back-up" surgery for percutaneous patients but more importantly on the quality of patient evaluation and selection, decision-making, intraprocedure management, and postprocedure care and outcomes.

A cardiac surgeon and an interventional cardiologist must evaluate every case. Interplay between interventional cardiologists and cardiac surgeons represent only part of the benefit of the MDT. ${ }^{1}$ As noted above, additional critical contributions are provided by cardiac anesthesiologists, by imaging specialists in both cardiology and radiology, and by the many people who extend beyond the physician members of the team. The MDT is led by a core of physicians from interventional cardiology, cardiac surgery, cardiac anesthesiology, and intensive care and cardiac imaging departments, along with congenital heart disease specialists and surgeons, in some instances. Depending on the institutional organization and the needs of the patient, vascular surgery and interventional radiology departments may also participate in the MDT. Additional team members include NPs from all of these fields, research coordinators, and a dedicated administrator.

The function of the MDT is essential in preprocedure patient selection, intraprocedure management and problem solving, postprocedure management, postdischarge followup, and outcome studies. During procedures, emergencies or unanticipated needs may arise as a matter of course even in the most straightforward situation. The immediate availability of MDT support to help with decision-making or with therapy is essential. A clear definition of roles for different specialties as well as effective communication, which may be different from that of conventional procedures, is critical for successful outcomes. Difficult postprocedure courses are common in the high-risk patients who comprise a large part of the target population for both transcatheter and operative valve therapies. A team approach to problem solving in this setting is critical. Another important part of patient management is the familiarity that the intensive care unit and the monitored step-down floor staff have with the specific details of each form of valve therapy. After the postprocedure management phase, long-term, posthospital follow-up for this select group of patients is also part of the MDT's responsibility. Planning for and resourcing this important phase of care is incumbent on the MDT. Post approval registries (eg, STS/ACC TVT Registry) ${ }^{1}$ will be required for many of the new transcatheter valve therapies, and, therefore, a data collection/ research unit within the MDT is another required component.

For sites with no prior trial experience in aortic transcatheter therapies, background experience from related procedures is important. The surgical use of ventricular assist device support or apical conduit therapy for aortic stenosis or left ventricular apical venting during aortic aneurysm procedures provides excellent experience for management of apical access for TAVR. For transcatheter procedures that do not directly involve the surgeon as a procedure operator, the role of the cardiac surgeon remains critically important. The surgeon has many roles and is often a patient advocate and/or referring physician, and is a necessary scientific study participant in all of these device applications. The surgeon is familiar with established standards of surgical care for application in transcatheter therapies and is frequently in charge of assessing high-risk patients for catheter-based therapy as an alternative to surgery. In a valve therapy program, neither the surgeon nor the cardiologist should be in charge of the assessment, but rather the MDT. In all transcatheter aortic procedures, the interventionalist and the surgeon should be present for the critical portions of the procedure.

Another mechanism for promoting a team approach that involves both surgeons and cardiologists is split or shared physician reimbursement for these procedures, which this writing group strongly endorses. This important principle will ensure that surgeons and cardiologists participate jointly in performing procedures, and that each patient receives the best and most patient-centered treatment.

The MDT should meet formally as a group on a regular basis (aside from the usual "cath conference") to review all patients referred for procedures, performance of recent 
procedures (to discuss both favorable and unfavorable outcomes), and follow-up of prior procedures.

\section{FUNCTION OF THE MDT}

Programmatic success depends on the ability of the MDT to function effectively in the best interest of a given patient. To do so, the MDT must work cohesively through the processes of patient selection, procedural planning, procedural conduct, periprocedural care, and longitudinal follow-up. ${ }^{1}$ Through each phase of this continuum, the individual skills of the MDT members should be brought to bear on the process.

The procedural success of transcatheter valve therapies begins with patient selection. Given the complexity of the decision-making process surrounding these procedures, it is necessary that all MDT members provide objective input and judgments from the outset of a patient evaluation. ${ }^{1}$ In order that true informed consent be obtained, the patient must remain at the center of the deliberations of the MDT at all times, and must be involved in the discussions regarding her/his therapeutic approach and goals. The patient selection process may be initiated by use of regularly scheduled patient selection conferences attended by all MDT members. Such conferences are analogous to transplant patient selection committee meetings, and provide a venue in which patient-specific data and imaging are formally presented and discussed by the MDT. The respective expertise of each discipline represented among MDT members may then be synthesized into a patient-specific recommendation.

Direct patient evaluation by cardiologists and cardiac surgeons may be accomplished jointly and, if possible, simultaneously in a venue such as a multidisciplinary valve program clinic. Not only does such a clinic provide convenience for the many patients who are elderly and fragile, but it also provides an opportunity for cardiac surgeons and cardiologists to jointly examine and evaluate complex patients.

In so doing, the expertise and judgment of both disciplines may be woven into a patient-specific decision. The participation of anesthesiologists in these clinics may also be useful.

Following the decision that a given patient is an appropriate candidate for TAVR, the procedure must then be carefully planned. Cardiac surgical teams are familiar with, and routinely use the concept of, "preprocedure briefings" before complex cardiac surgical operations. In such briefings, all team members (ie, surgeons, anesthesiologists, perfusionists, nurses, and technicians) discuss the intended procedure, including the steps of the planned procedure, the specific tools and equipment needed (beyond those typically used), the possible complications that may arise during the course of the procedure, and the contingency plans that will be implemented should the unexpected occur. ${ }^{1}$ All members of the team may then initiate the planned procedure with a common understanding of its conduct and what will happen if the plan needs to change.

As integral members of the MDT, the cardiologist, cardiovascular surgeon, and the catheterization team will participate actively in this preprocedure planning and MDT briefing, which is so important for the procedural success of transcatheter valve therapies. During the procedure, emergency situations and unexpected needs may arise. The immediate availability of MDT physician support in emergency decision-making and therapy is essential. It is, therefore, important that the roles of the various specialties be clearly delineated during preprocedure planning.

Patients who undergo transcatheter valve therapies are often elderly and frail with multiple comorbidities. Postprocedure care of such patients may be difficult and entail the management of multiple organ system dysfunctions. In many cases, the initial postprocedure care should be provided in an intensive care setting. A team approach to the care of these patients and to problem solving is important and should include physicians skilled in critical care medicine. Once in-patients are able to leave the intensive care environment, they should be attended by a unit specializing in the care of patients with cardiac diseases, and this unit should be equipped with telemetry-monitored beds. Again, a team approach is important for success. The team of physicians, nurses, occupational and physical therapists, and other members must have an understanding of the pathophysiology of the particular valve condition, as well as the nuances of care for patients who have undergone cardiac surgery and interventional cardiology procedures.

Procedural success of transcatheter valve therapies must be determined via longitudinal outcomes. Long-term follow-up of these patients is an important element of the MDT approach. Post-FDA approval registries (eg, STS/ ACC TVT Registry) will be required for most transcatheter valve therapies. ${ }^{1}$ Therefore, a long-term relationship between the patient and the MDT must be established to undertake the needed alterations in medical therapy, serial echocardiographic imaging, and monitoring of devices. Likewise, changes in patient functional status, heart failure class, potential device-related complications, and other such conditions must be carefully tracked. A valve program clinic can provide a venue for this type of long-term follow-up.

The postmarket surveillance of transcatheter valve devices will be an extremely important function of the MDT. Participation in device-specific registries (eg, STS/ ACC TVT Registry) can be challenging and requires an institutional infrastructure and commitment that includes experienced data managers with a background in cardiac disease, funding, office space, and computer resources. It requires a clinical research unit with rigorous attention to detail, and the collection of accurate data as an integral part of the function of the MDT. 


\section{CRITERIA FOR ESTABLISHING A TRANSCATHETER VALVE PROGRAM AND MAINTENANCE OF COMPETENCE}

An important issue in the establishment of a transcatheter valve program is the clinical or referral base for ensuring an adequate number of patients to provide for the viability of a program. The requirements for the establishment of a successful transcatheter valve program are described in Table 1.

Once chosen for participation as TAVR programs, either as existing programs, or as new programs, to maintain ongoing approval for participation, sites will be monitored to ensure that they continue to satisfy both the volume and outcomes criteria as described in Table 2.

Unlike the experience with PCI, where data attest to the relationship between the volume of procedures and outcomes, there are little or no data on which to draw conclusions as to the volume-outcome relationship for TAVR. Therefore, these recommendations are constructed to: (1) ensure patient safety, (2) demonstrate that there is a commitment on the part of the institution to the structural heart disease program, and (3) use existing volume as a surrogate for an established valve program to ensure adequate patient volumes for the establishment of a sustainable and highquality transcatheter valve program. As experience grows and more data become available, these recommendations will undoubtedly be refined.

\section{AORTIC VALVE REPLACEMENT}

Surgical aortic valve replacement is the treatment of choice for patients with severe aortic valve disease. ${ }^{1}$ However, a significant percentage of those patients are not offered the procedure or simply refuse to undergo it on the basis of excessive risks, both real and perceived. ${ }^{21}$ It is in this context that the possibility of transcatheter aortic valve implantation has become a reality for patients outside of the United States. Furthermore, the cohort B results of the PARTNER (Placement of Aortic Transcatheter) trial (nonoperable patients) would indicate that medical therapy, including BAV, should be reserved only for patients who do not qualify for the procedure on the basis of their anatomy or clinical characteristics. ${ }^{22}$ Considering the reports of successful transcatheter treatment of aortic valve stenosis using balloons $^{23}$ and subsequent reports of poor long-term outcomes due to early restenosis, ${ }^{24}$ the idea of developing a transcatheter aortic valve was a logical progression. Initial animal studies $^{25}$ and subsequent human implantations have led to the progressive development of this technology.

Results from the PARTNER trial using the Edwards Sapien Valve (Edwards Lifesciences, Irvine, Calif), the first randomized trial of this technology, have established its place as a treatment of severe symptomatic aortic stenosis. $^{22-26}$ The trial consisted of 2 arms: cohort A $(n=699)$, the high risk surgical group, which randomized patients to surgical aortic valve replacement or TAVR, and cohort B ( $\mathrm{n}=358$ ), the nonsurgical group randomized to medical therapy, which could include valvuloplasty or TAVR. Results from the noninferiority cohort A group showed a 1 year all-cause mortality of $26.8 \%$ in the surgical arm and $24.2 \%$ in the TAVR arm, a hazard ratio (HR) $(95 \%$ CI) of $0.93(0.7,1.22)$, which met the noninferiority endpoint, $P=.001$ (for a noninferiority margin of 7.5 percentage points). There were differences in outcomes between the groups, the most worrisome being a higher incidence of stroke or transient ischemic attack (TIA) at 30 days and at 1 year in the TAVR arm (at 30 days: $5.5 \%$ vs $2.4 \%, P=.04$ and at 1 year: $8.3 \%$ vs $4.3 \%, P=.04$ ). The need for a new permanent pacemaker was not different between the groups, 5.7\% in the surgical arm versus $5.0 \%$ in the TAVR arm, $P=.68$. In cohort B, TAVR was found to be superior to medical therapy with an all-cause mortality at 1 year of $50.7 \%$ in the medical arm versus $30.7 \%$ in the TAVR arm, HR (95\% CI) $0.54(0.58,0.78, P<.001)$. These findings suggest that it is necessary to treat 5 patients to prevent 1 death. ${ }^{27}$ PARTNER II, which uses a new, lower profile delivery system, is in the early stages of patient recruitment. To date, there are no randomized data regarding the CoreValve prosthesis (Medtronic, Minneapolis, Minn) but it has received the CE mark in Europe, as has the Sapien valve.

Registry data appear to show favorable hemodynamic outcomes and acceptable mortality. ${ }^{28,29}$ In this large multicenter registry consisting of 14 centers reporting on 663 consecutive patients, ${ }^{29}$ procedure success was $98 \%$ with a procedural mortality of $0.9 \%$. Thirty-day mortality was $5.4 \%$ and $15.0 \%$ at 1 year. Stroke during the procedure and at 1 year was $1.2 \%$ and $2.5 \%$, respectively. The requirement for a permanent pacemaker was $19.1 \%$ at 1 year, a rate similar to other registries reporting outcomes using this valve. Independent predictors of mortality at 30 days included conversion to open heart surgery (odds ratio [OR], 38.68), cardiac tamponade (OR, 10.97), major access site complications (OR, 8.47), left ventricular ejection fraction $<40 \%(\mathrm{OR}, 3.51)$, prior balloon valvuloplasty (OR, 2.87), and diabetes mellitus (OR, 2.66). Predictors of late mortality (30 days to 1 year) included prior stroke (HR, 5.47), post procedural paravalvular leak is $\geq 2+$ (HR, 3.79), prior acute pulmonary edema (HR, 2.70), and chronic kidney disease (HR, 2.53). The CoreValve US Pivotal Trial is currently randomizing patients in a similar fashion to the PARTNER trial and should yield additional important data on this valve.

\section{RESEARCH/REGISTRY}

FDA clearance of a novel valve repair or replacement prosthesis does not guarantee that the device will continue to demonstrate long-term efficacy equal to currently 
available options, or that its application will be limited to the initially approved patient subsets. Postmarket studies organized through individual institutions or multicenter study groups and registries managed by industry and professional societies are essential for ensuring continued short-term safety, and for determining long-term efficacy. Only with such data can we consider application of new valve prostheses to a wider patient population outside the boundaries of the study groups examined during FDA trials. Centers that incorporate transcatheter-based therapies into their practice absolutely must participate in a cardiac surgery or cardiology national database such as the STS National Database, Northern New England Cardiac Disease Study Group, American College of Cardiology's National Cardiovascular Data Registry, or an equivalent database. ${ }^{30-32}$ These databases facilitate continued analysis of early outcomes on a national level; however, most do not permit analysis of results beyond the 30-day window, mandating the development of implant registries with patient consent, permitting late follow-up for survival and valve-related complications and reinterventions. These valve repair and replacement procedures should be registered in databases capable of providing both acute outcome and longterm follow-up data.

Early postprocedure morbidity and mortality analyses, while important for initial and continued implant safety assessment, are not sufficient to evaluate the efficacy of valve repair or replacement prostheses. Studies on longterm follow-up survival and, more importantly, structural valve degeneration, and the need for reintervention, are essential. Recent attempts to link the STS National Database to an administrative survival database (Social Security Death Master File) or to CMS Medicare data have been promising; however, survival data alone will not be sufficient for transcatheter valve registries (eg, STS/ACC TVT Registry ${ }^{33}$ ). Risk adjustment using only administrative data is challenging and may be more important in this highly complex patient population. Transcatheter valve registries must incorporate late assessment of structural valve degeneration and the need for late reoperation or reintervention. Long-term function data is also essential before application of new valve repair or replacement technology can be considered for lower risk and younger patients. Clinicians must be careful not to extrapolate outcomes generated during FDA trials to patients that do not reasonably approximate the trial study populations. At present, it is not acceptable for clinicians to apply "off label" transcatheter techniques to patients who are otherwise excellent candidates for conventional valve repair or replacement outside the confines of a randomized, controlled trial or, at a minimum, multicenter, national, prospective studies.

The potential negative impact of a valve prosthesis recall, in regards to the increased risk associated with reoperative surgery for a permanent implant, far outweighs that associated with the removal of a pharmacologic agent from the market. ${ }^{34}$ Thus, the allocation of adequate funding to allow complete follow-up studies is essential, including financial support from industry, the FDA, National Institutes of Health, CMS, and professional societies, with scientific oversight distanced from industry and potential conflicts of interest. Postmarket surveillance governed solely by industry self-regulation can be of dubious value. In a 2005 editorial, Eugene Blackstone cautioned, "Industry has not developed a viable mechanism for dealing with 'bad news,' the disclosure of which often leads to the demise of the company." 35 The Interagency Registry for Mechanically Assisted Circulatory Support exemplifies a potentially efficient model that could be emulated by professional societies for monitoring transcatheter inventions during the next decade, during which durability data will be generated. ${ }^{36}$

Transcatheter valve repair or replacement devices are unique in that an understanding not only of early risk, but also of long-term durability, is essential for determining the appropriate patient subgroups for these therapies. In our opinion, it is the responsibility of professional societies to ensure adequate long-term data monitoring and provide oversight and guidance to industry on the expectations for continued monitoring beyond the FDA approval phase of device development and implementation. Individual centers are also responsible for critically evaluating their own experience, through local and regional quality improvement initiatives, and for participating in national databases and registries (eg, STS/ACC TVT Registry) that facilitate continued safety and efficacy in the assessment of novel, and, as yet, unproven, therapeutic options. Components of a national/international registry should include preoperative risk factors and valve assessment, intraoperative details, early postoperative morbidity, and late follow-up including survival, need for reintervention, functional class, devicerelated complications, and late assessment of valve performance. It is inappropriate to perform these novel and innovative procedures without the institutional infrastructure to ensure adequate early data collection and later follow-up.

\section{References}

1. Holmes DR Jr, Mack MJ, Kaul S, Agnihotri A, Alexander KP, et al. 2012 ACCF/ AATS/SCAI/STS expert consensus document on transcatheter aortic valve replacement. J Am Coll Cardiol. 2012;59:1200-54.

2. Ruiz CE, Feldman TE, Hijazi ZM, Holmes DR Jr, Webb JG, et al. Interventional fellowship in structural and congenital heart disease for adults. J Am Coll Cardiol Intv. 2010;3:e1.

3. Feldman T, Ruiz CE, Hijazi ZM. The SCAI Structural Heart Disease Council: toward addressing training, credentialing, and guidelines for structural heart disease intervention. Catheter Cardiovasc Interv. 2010;76:E87-9.

4. Vassiliades TA Jr, Block PC, Cohn LH, Adams DH, Borer DR, et al. The clinical development of percutaneous heart valve technology: a position statement of the Society of Thoracic Surgeons (STS), the American Association for Thoracic Surgery (AATS), and the Society of Cardiovascular Angiography and Interventions (SCAI). Catheter Cardiovasc Interv. 2005;65:73-9.

5. Herrmann HC, Baxter S, Ruiz CE, Feldman TE, Hijazi ZM, et al. Results of the society of cardiac angiography and interventions survey of physicians and 
training directors on procedures for structural and valvular heart disease. Catheter Cardiovasc Interv. 2010;76:E106-10.

6. Cameron A, Laskey W, Sheldon W. SCAI ad hoc task force on ethics in invasive and interventional cardiology. Catheter Cardiovasc Interv. 2004;61:157-62.

7. Kouchoukos NT, Bavaria JE, Coselli JS, De la Torre R, Ikonomidis JS, et al. Guidelines for credentialing of practitioners to perform endovascular stentgrafting of the thoracic aorta. J Thorac Cardiovasc Surg. 2006;131:530-2.

8. Beller GA, Winters WL Jr, Carver JR, King SB, McCallister BD, et al. 28th Bethesda Conference. Task Force 3: Guidelines for credentialling practicing physicians. J Am Coll Cardiol. 1997;29:1148-62.

9. Advisory Council for Cardiothoracic Surgery, American College of Surgeons. Guidelines for standards in cardiac surgery. Bull Am Coll Surg. 1997;82:27-9.

9a. Valve Academic Valve Consortium. Revised standardized endpoint definitions for transcatheter aortic valve implantation (VARC-2). Manuscript in preparation.

10. Vahanian A, Alfieri OR, Al-Attar N, Antunes MJ, Bax J, et al. Transcatheter valve implantation for patients with aortic stenosis: A position statement from the European Association of Cardio-Thoracic Surgery (EACTS) and the European Society of Cardiology (ESC), in collaboration with the European Association of Percutaneous Cardiovascular Interventions (EAPCI). Eur J Cardiothorac Surg. 2008;34:1-8.

11. Peterson ED, Coombs LP, DeLong ER, et al. Procedural volume as a marker of quality for CABG surgery. JAMA. 2004;291:195-201.

12. Crawford FA, Anderson RP, Clark RE, Grover FL, Kouchoukos NT, et al. Volume requirements for cardiac surgery credentialing: a critical examination. Ann Thorac Surg. 1996;61:12-6.

13. Bashankaev B, Baido S, Wexner SD. Review of available methods of simulation training to facilitate surgical education. Surg Endosc. 2011;25:28-35.

14. Hislop SJ, Hedrick JH, Singh MJ, Rhodes JM, Gillespie DL, et al. Simulation case rehearsals for carotid artery stenting. Eur J Vasc Endovasc Surg. 2009;38:750-4.

15. Cacho F, Doblare M, Holzapfel GA. A procedure to simulate coronary artery bypass graft surgery. Med Biol Eng Comput. 2007;45:819-27.

16. Tedesco MM, Pak JJ, Harris EJ Jr, Krummel TM, Dalman RL, et al. Simulationbased endovascular skills assessment: the future of credentialing? J Vasc Surg. 2008;47:1008-16; discussion, 1014.

17. Seymour NE, Gallaher AG, Roman SA, O'Brien MK, Bansal VK, et al. Virtual reality training improves operating room performance: results of a randomized, double-blinded study. Ann Surg. 2002;236:458-63; discussion, 463-4.

18. Bonow RO, Carabello BA, Chatterjee K, Leon de JR AC, Faxon DP, et al. 2008 Focused update incorporated into the acc/aha 2006 guidelines for the management of patients with valvular heart disease: a report of the American College of Cardiology/American Heart Association Task Force on Practice Guidelines (Writing Committee to Revise the 1998 Guidelines for the Management of Patients With Valvular Heart Disease). J Am Coll Cardiol. 2008;52:e1-140.

18a. Bashore TM, Balter S, Barac A, et al. 2012 American College of Cardiology Foundation Society for Cardiovascular Angiography and Interventions expert consensus document on cardiac catheterization laboratory standards update. $J$ Am Coll Cardiol. May 8, 2012 [Epub ahead of print]; doi:10.1016/ j.jacc.2012.02.010
19. Neily J, Mills PD, Young-Xu Y, Carney BT, West P, et al. Association between implementation of a medical team training program and surgical mortality. JAMA. 2010;304:1693-700.

20. Hijazi ZM, Feldman T, Al-Qbandi MH, et al. Transcatheter Closure of ASDs and PFOs: A Comprehensive Assessment. Minneapolis, MN: CardioText Publishing; 2010:390.

21. Bach DS, Siao D, Girard SE, Duvernoy C, McCallister BD, et al. Evaluation of patients with severe symptomatic aortic stenosis who do not undergo aortic valve replacement. Circ: Cardiovasc Qual Outcomes. 2009;2:533-9.

22. Leon MB, Smith CR, Mack M, Miller DC, Moses JW, et al. Transcatheter aorticvalve implantation for aortic stenosis in patients who cannot undergo surgery. N Engl J Med. 2010;363:1597-607.

23. Cribier A, Savin T, Saoudi N, Rocha P, Berland J, et al. Percutaneous transluminal valvuloplasty of acquired aortic stenosis in elderly patients: an alternative to valve replacement? Lancet. 1986;327:63-7.

24. Bashore TM, Davidson CJ. Follow-up recatheterization after balloon aortic valvuloplasty. J Am Coll Cardiol. 1991;17:1188-95.

25. Andersen HR, Knudsen LL, Hasenkam JM. Transluminal implantation of artificial heart valves. Description of a new expandable aortic valve and initial results with implantation by catheter technique in closed chest pigs. Euro Heart J. 1992; 13:704-8.

26. Smith CR, Leon MB, Mack MJ, Miller DC, Moses JW, Svensson LG, et al. Transcatheter versus surgical aortic-valve replacement in high-risk patients. $N$ Engl J Med. 2011;364:2187-98

27. Alfieri O, Maisano F, De Bonis M, Stefano PL, Torracca L, et al. The doubleorifice technique in mitral valve repair: a simple solution for complex problems. J Thorac Cardiovasc Surg. 2001;122:674-81.

28. Grube E, Schuler G, Gerckens U, Wenaweser P, Mohr F-W, et al. Percutaneous aortic valve replacement for severe aortic stenosis in high-risk patients using the second- and current third-generation self-expanding CoreValve prosthesis: device success and 30-day clinical outcome. J Am Coll Cardiol. 2007;50:69-76.

29. Tamburino C, Capodanno D, Ramondo A, Petronio AS, Ettori F, et al. Incidence and predictors of early and late mortality after transcatheter aortic valve implantation in 663 patients with severe aortic stenosis. Circulation. 2011;123:299-308

30. Society of Thoracic Surgeons National Database. Available at: http://www.sts. org/national-database. Accessed August 17, 2011.

31. American College of Cardiology National Cardiovascular Data Registry. Available at: http://www.ncdr.com/WebNCDR/Common/. Accessed August 17, 2011

32. Jacobs JP, Edwards FH, Shahian DM, Prager RL, Wright CD, et al. Successfu linking of the Society of Thoracic Surgeons database to Social Security data to examine survival after cardiac operations. Ann Thorac Surg. 2011;92:32-7; discussion, 38-9.

33. Topol EJ. Failing the public health-rofecoxib, Merck, and the FDA. $N$ Engl J Med. 2004;351:1707-9.

34. Fontanarosa PB, Rennie D, DeAngelis CD. Postmarketing surveillance-lack of vigilance, lack of trust. JAMA. 2004;292:2647.

35. Blackstone EH. Could it happen again? Circulation. 2005;111:2717-9.

36. Interagency Registry for Mechanically Assisted Circulatory Support. Available at: http://www.intermacs.org. Accessed August 18, 2011 
APPENDIX E1. Author relationships with industry and other entities (relevant)-Multisociety (AATS, ACCF, SCAI, and STS) expert consensus statement: Operator and institutional requirements for transcatheter valve repair and replacement, part 1: Transcatheter valve repair and replacement

\begin{tabular}{|c|c|c|c|c|c|c|c|}
\hline $\begin{array}{l}\text { Committee } \\
\text { member }\end{array}$ & Employment & Consultant & $\begin{array}{c}\text { Speaker's } \\
\text { bureau }\end{array}$ & $\begin{array}{l}\text { Ownership/ } \\
\text { partnership/ } \\
\text { principal }\end{array}$ & $\begin{array}{l}\text { Personal } \\
\text { research }\end{array}$ & $\begin{array}{c}\text { Institutional, } \\
\text { organizational, or } \\
\text { other financial } \\
\text { benefit }\end{array}$ & $\begin{array}{l}\text { Expert } \\
\text { witness }\end{array}$ \\
\hline Michael A. Acker & $\begin{array}{l}\text { Hospital of the } \\
\text { University of } \\
\text { Pennsylvania- } \\
\text { Chief, Division of } \\
\text { Cardiovascular } \\
\text { Surgery }\end{array}$ & None & None & None & None & None & None \\
\hline Gabriel S. Aldea & $\begin{array}{l}\text { University of } \\
\text { Washington } \\
\text { Medical- } \\
\text { Associate } \\
\text { Professor }\end{array}$ & None & None & None & None & None & None \\
\hline Joseph Bavaria* & $\begin{array}{l}\text { Hospital of the } \\
\text { University of } \\
\text { Pennsylvania } \\
\text { Health System } \\
\text { Cardiothoracic } \\
\text { Surgery_-Vice- } \\
\text { Chief, Division of } \\
\text { Cardiothoracic } \\
\text { Surgery; Brooke } \\
\text { Roberts-William } \\
\text { M. Measey } \\
\text { Professor of } \\
\text { Surgery; } \\
\text { Director, } \\
\text { Thoracic Aortic } \\
\text { Surgery Program }\end{array}$ & $\begin{array}{l}\text { St. Jude } \\
\text { Medical }\end{array}$ & None & None & $\begin{array}{l}\text { Medtronic } \\
\text { Vascular }\end{array}$ & $\begin{array}{l}\text { Edwards } \\
\text { Lifesciences } \dagger \\
\text { Medtronic } \dagger\end{array}$ & None \\
\hline $\begin{array}{l}\text { R. Morton (Chip) } \\
\text { Bolman }\end{array}$ & $\begin{array}{l}\text { Harvard Medical } \\
\text { School-Chief, } \\
\text { Division of } \\
\text { Cardiac Surgery; } \\
\text { Professor of } \\
\text { Surgery }\end{array}$ & None & None & None & None & None & None \\
\hline Duke Cameron & $\begin{array}{l}\text { The Johns Hopkins } \\
\text { Hospital }\end{array}$ & None & None & None & None & None & None \\
\hline Larry Dean* & $\begin{array}{l}\text { University of } \\
\text { Washington } \\
\text { School of } \\
\text { Medicine- } \\
\text { Professor of } \\
\text { Medicine and } \\
\text { Surgery }\end{array}$ & $\begin{array}{l}\text { Emageon } \\
\text { Philips Medical }\end{array}$ & None & None & $\begin{array}{l}\text { Edwards } \\
\quad \text { Lifesciences } \ddagger\end{array}$ & None & None \\
\hline Ted Feldman* & $\begin{array}{l}\text { Evanston } \\
\text { Northwestern } \\
\text { Healthcare } \\
\text { Cardiology } \\
\text { Division-- } \\
\text { Director, Cardiac } \\
\text { Catheterization } \\
\text { Laboratory }\end{array}$ & $\begin{array}{l}\text { Abbott } \\
\text { Boston Scientific } \\
\text { Edwards } \\
\quad \text { Lifesciences } \\
\text { W.L. Gore }\end{array}$ & None & None & $\begin{array}{l}\text { Abbott } \\
\text { Boston Scientific } \dagger \\
\text { Edwards } \\
\quad \text { Lifesciences } \\
\text { W.L. Gore }\end{array}$ & None & None \\
\hline
\end{tabular}




\begin{tabular}{|c|c|c|c|c|c|c|c|}
\hline $\begin{array}{c}\text { Committee } \\
\text { member }\end{array}$ & Employment & Consultant & $\begin{array}{c}\text { Speaker's } \\
\text { bureau }\end{array}$ & $\begin{array}{c}\text { Ownership/ } \\
\text { partnership/ } \\
\text { principal }\end{array}$ & $\begin{array}{l}\text { Personal } \\
\text { research }\end{array}$ & $\begin{array}{c}\text { Institutional, } \\
\text { organizational, or } \\
\text { other financial } \\
\text { benefit }\end{array}$ & $\begin{array}{l}\text { Expert } \\
\text { witness } \\
\end{array}$ \\
\hline David Fullerton & $\begin{array}{l}\text { University of } \\
\text { Colorado School } \\
\text { of Medicine- } \\
\text { Chief, } \\
\text { Cardiothoracic } \\
\text { Surgery }\end{array}$ & None & None & None & None & None & None \\
\hline Ziyad M. Hijazi* & $\begin{array}{l}\text { Rush University } \\
\text { Medical } \\
\text { Center- } \\
\text { Professor, } \\
\text { Pediatrics and } \\
\text { Internal } \\
\text { Medicine; } \\
\text { Director for the } \\
\text { Center of } \\
\text { Congenital and } \\
\text { Structural Heart } \\
\text { Disease }\end{array}$ & $\begin{array}{l}\text { Edwards } \\
\quad \text { Lifesciences } \ddagger \\
\text { NuMED } \ddagger\end{array}$ & None & $\begin{array}{c}\text { Colibri Heart } \\
\text { Valve } \dagger\end{array}$ & None & None & None \\
\hline Eric Horlick* & $\begin{array}{l}\text { Toronto General } \\
\text { Hospital-Asst. } \\
\text { Professor of } \\
\text { Medicine, } \\
\text { University Health } \\
\text { Network }\end{array}$ & $\begin{array}{l}\text { Abbott Vascular } \\
\text { AGA } \ddagger \\
\text { Cordis } \\
\text { Edwards } \\
\quad \text { Lifesciences } \ddagger \\
\text { Medtronic } \\
\text { W.L. Gore }\end{array}$ & $\begin{array}{l}\text { Biosense } \\
\text { Webster }\end{array}$ & None & None & None & None \\
\hline D. Craig Miller* & $\begin{array}{l}\text { Stanford University } \\
\text { Medical School } \\
\text { Dept. } \\
\text { Cardiothoracic } \\
\text { Surgery- } \\
\text { Thelma and } \\
\text { Henry Doelger } \\
\text { Professor of } \\
\text { Cardiovascular } \\
\text { Surgery; } \\
\text { Cardiovascular } \\
\text { Surgical } \\
\text { Physiology } \\
\text { Research } \\
\text { Laboratories- } \\
\text { Director }\end{array}$ & $\begin{array}{l}\text { Abbott Vascular } \\
\text { MitraClip } \\
\text { Medtronic } \\
\text { Cardiovascular } \\
\quad \text { Division } \\
\text { St. Jude Medical }\end{array}$ & None & None & $\begin{array}{l}\text { Edwards } \\
\text { Lifesciences } \\
\text { (PARTNER } \\
\text { Trial) } \dagger\end{array}$ & $\begin{array}{l}\text { Edwards } \\
\text { Lifesciences } \\
\text { (PARTNER } \\
\text { Trial) } \dagger\end{array}$ & None \\
\hline Marc R. Moon & $\begin{array}{l}\text { Barnes-Jewish } \\
\text { Hospital—Joseph } \\
\text { Bancroft } \\
\text { Professor of } \\
\text { Surgery, Division } \\
\text { of Cardiothoracic } \\
\text { Surgery; Program } \\
\text { Director, } \\
\text { Thoracic Surgery } \\
\text { Residency } \\
\text { Program }\end{array}$ & None & None & None & None & None & None \\
\hline
\end{tabular}




\begin{tabular}{|c|c|c|c|c|c|c|c|}
\hline $\begin{array}{l}\text { Committee } \\
\text { member }\end{array}$ & Employment & Consultant & $\begin{array}{c}\text { Speaker's } \\
\text { bureau }\end{array}$ & $\begin{array}{c}\text { Ownership/ } \\
\text { partnership/ } \\
\text { principal }\end{array}$ & $\begin{array}{l}\text { Personal } \\
\text { research }\end{array}$ & $\begin{array}{c}\text { Institutional, } \\
\text { organizational, or } \\
\text { other financial } \\
\text { benefit }\end{array}$ & $\begin{array}{l}\text { Expert } \\
\text { witness }\end{array}$ \\
\hline Richard R. Ringel & $\begin{array}{l}\text { Johns Hopkins } \\
\text { School of } \\
\text { Medicine- } \\
\text { Associate } \\
\text { Professor of } \\
\text { Pediatrics }\end{array}$ & None & None & None & None & None & None \\
\hline Carlos E. Ruiz & $\begin{array}{l}\text { Lenox Hill Heart } \\
\text { and Vascular } \\
\text { Institute of New } \\
\text { York-Professor } \\
\text { and Chief, } \\
\text { Division of } \\
\text { Pediatric } \\
\text { Cardiology }\end{array}$ & None & None & None & None & None & None \\
\hline Carl Tommaso & $\begin{array}{l}\text { North Shore } \\
\text { University } \\
\text { HealthSystem- } \\
\text { Medical Director } \\
\text { of Cardiac Cath } \\
\text { Lab }\end{array}$ & None & None & None & None & None & None \\
\hline Alfred Trento & $\begin{array}{l}\text { Cedar Sinai Medical } \\
\text { Center-Director } \\
\text { of Division of } \\
\text { Cardiothoracic } \\
\text { Surgery }\end{array}$ & None & None & None & None & None & None \\
\hline Bonnie Weiner $^{\mathrm{a}}$ & $\begin{array}{l}\text { Saint Vincent } \\
\text { Hospital at } \\
\text { Worcester } \\
\text { Medical Center/ } \\
\text { Fallon Clinic- } \\
\text { Director of } \\
\text { Interventional } \\
\text { Cardiology } \\
\text { Research; } \\
\text { Imaging Core } \\
\text { Lab Services- } \\
\text { President; Boston } \\
\text { Biomedical } \\
\text { Associates- } \\
\text { Medical Director }\end{array}$ & $\begin{array}{c}\text { LabCoat/Boston } \\
\text { Scientific } \ddagger\end{array}$ & Medtronic & None & None & $\begin{array}{l}\text { Accreditation for } \\
\text { Cardiovascular } \\
\text { Excellence } \ddagger \\
\text { Imaging Core Lab } \\
\text { Services } \dagger\end{array}$ & None \\
\hline Evan M. Zahn & $\begin{array}{l}\text { Miami Children's } \\
\text { Hospital— } \\
\text { Director of } \\
\text { Cardiology }\end{array}$ & $\begin{array}{l}\text { Medtronic } \dagger \\
\text { Edwards } \\
\quad \text { Lifesciences } \dagger\end{array}$ & None & None & None & None & None \\
\hline
\end{tabular}

This table represents the relationships of committee members with industry and other entities that were determined to be relevant to this document. These relationships were reviewed and updated in conjunction with all meetings and/or conference calls of the writing committee during the document development process. The table does not necessarily reflect relationships with industry at the time of publication. A person is deemed to have a significant interest in a business if the interest represents ownership of $5 \%$ or more of the voting stock or share of the business entity, or ownership of $\geq \$ 10,000$ of the fair market value of the business entity; or if funds received by the person from the business entity exceed $5 \%$ of the person's gross income for the previous year. Relationships that exist with no financial benefit are also included for the purpose of transparency. Relationships in this table are modest unless otherwise noted. Please refer to http://www.cardiosource.org/Science-And-Quality/Practice-Guidelines-and-Quality-Standards/Relationships-With-Industry-Policy.aspx for definitions of disclosure categories or additional information about the ACCF Disclosure Policy for Writing Committees. According to the ACCF, a person has a relevant relationship IF: (a) The relationship or interest relates to the same or similar subject matter, intellectual property or asset, topic, or issue addressed in the document; or (b) The company/entity (with whom the relationship exists) makes a drug, drug class, or device addressed in the document, or makes a competing drug or device addressed in the document; or (c) The person or a member of the person's household, has a reasonable potential for financial, professional or other personal gain or loss as a result of the issues/content addressed in the document. * Recused from writing initial text and voting on document recommendations due to relevant relationships with industry to this document. $†$ No financial benefit. $\ddagger$ Significant relationship. 
APPENDIX E2. Reviewer relationships with industry and other entities (relevant)—Multisociety (AATS, ACCF, SCAI, and STS) expert consensus statement: Operator and institutional requirements for transcatheter valve repair and replacement, part 1: Transcatheter valve repair and replacement

\begin{tabular}{|c|c|c|c|c|c|c|c|c|}
\hline Peer reviewer & Representation & Employment & Consultant & $\begin{array}{l}\text { Speaker's } \\
\text { bureau }\end{array}$ & $\begin{array}{c}\text { Ownership/ } \\
\text { partnership/ } \\
\text { principal }\end{array}$ & Personal research & $\begin{array}{c}\text { Institutional, } \\
\text { organizational, or } \\
\text { other financial } \\
\text { benefit }\end{array}$ & Expert witness \\
\hline Deepak L. Bhatt & $\begin{array}{l}\text { Official Reviewer- } \\
\text { ACCF Task Force } \\
\text { on Clinical Expert } \\
\text { Consensus } \\
\text { Documents }\end{array}$ & $\begin{array}{l}\text { VA Boston Health } \\
\text { Care System- } \\
\text { Chief, Division of } \\
\text { Cardiology }\end{array}$ & None & None & None & $\begin{array}{l}\text { Medtronic* } \\
\text { Ethicon* }\end{array}$ & None & None \\
\hline 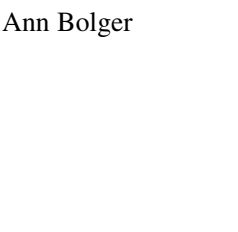 & $\begin{array}{l}\text { Content Reviewer- } \\
\text { ACCF/AHA/ACP } \\
\text { Task Force on } \\
\text { Clinical } \\
\text { Competence and } \\
\text { Training }\end{array}$ & $\begin{array}{l}\text { University of } \\
\text { California, San } \\
\text { Francisco- } \\
\text { Professor of } \\
\text { Medicine }\end{array}$ & None & None & None & None & None & None \\
\hline Emmanouil Brilakis & $\begin{array}{l}\text { Content Reviewer- } \\
\text { ACCF } \\
\text { Interventional } \\
\text { Scientific Council }\end{array}$ & $\begin{array}{l}\text { UT Southwestern } \\
\text { Medical } \\
\text { School- } \\
\text { Director, Cardiac } \\
\text { Catheterization } \\
\text { Laboratory, VA } \\
\text { North Texas } \\
\text { Healthcare } \\
\text { System }\end{array}$ & St. Jude* & None & None & None & $\begin{array}{l}\text { Abbott Vascular* } \\
\text { Infraredx* } \\
\text { Medtronic* }\end{array}$ & None \\
\hline John H. Calhoon & $\begin{array}{l}\text { Official Reviewer- } \\
\text { STS }\end{array}$ & $\begin{array}{l}\text { University of Texas } \\
\text { Health Sciences } \\
\text { Center- } \\
\text { Professor and } \\
\text { Chair, } \\
\text { Department of } \\
\text { Cardiothoracic } \\
\text { Surgery }\end{array}$ & None & None & None & None & None & None \\
\hline George Dangas & $\begin{array}{l}\text { Content Reviewer- } \\
\text { ACCF } \\
\text { Interventional } \\
\text { Scientific Council }\end{array}$ & $\begin{array}{l}\text { Mount Sinai } \\
\text { Medical Center- } \\
\text { Program Director, } \\
\text { Interventional } \\
\text { Cardiology }\end{array}$ & $\begin{array}{l}\text { Abbott } \\
\text { Boston Scientific } \\
\text { Johnson \& Johnson } \\
\text { Medtronic } \\
\text { St. Jude Medical }\end{array}$ & None & None & None & $\begin{array}{l}\text { Abbott Vascular } \dagger \\
\text { Infraredx } \dagger \\
\text { Medtronic } \dagger \\
\text { W.L. Gore } \dagger\end{array}$ & $\begin{array}{l}\text { Plaintiff, stroke, } \\
2011\end{array}$ \\
\hline
\end{tabular}




\begin{tabular}{|c|c|c|c|c|c|c|c|c|}
\hline Peer reviewer & Representation & Employment & Consultant & $\begin{array}{c}\text { Speaker's } \\
\text { bureau }\end{array}$ & $\begin{array}{c}\text { Ownership/ } \\
\text { partnership/ } \\
\text { principal }\end{array}$ & Personal research & $\begin{array}{c}\text { Institutional, } \\
\text { organizational, or } \\
\text { other financial } \\
\text { benefit }\end{array}$ & Expert witness \\
\hline Fred H. Edwards & $\begin{array}{l}\text { Official Reviewer- } \\
\text { STS }\end{array}$ & $\begin{array}{l}\text { Shands } \\
\text { Jacksonville- } \\
\text { University of } \\
\text { Florida- } \\
\text { Professor of } \\
\text { Surgery; Chief, } \\
\text { Cardiothoracic } \\
\text { Surgery }\end{array}$ & None & None & None & None & None & None \\
\hline James I. Fann & $\begin{array}{l}\text { Official Reviewer- } \\
\text { AATS }\end{array}$ & $\begin{array}{l}\text { Stanford University } \\
\text { School of } \\
\text { Medicine }\end{array}$ & None & None & None & Medtronic $\dagger$ & None & None \\
\hline James Fasules & $\begin{array}{l}\text { Senior Vice } \\
\text { President, } \\
\text { Advocacy }\end{array}$ & $\begin{array}{l}\text { American College } \\
\text { of Cardiology }\end{array}$ & None & None & None & None & None & None \\
\hline T. Bruce Ferguson & $\begin{array}{l}\text { Content Reviewer- } \\
\text { ACCF } \\
\text { Interventional } \\
\text { Scientific Council }\end{array}$ & $\begin{array}{l}\text { East Carolina Heart } \\
\text { Institute Brody } \\
\text { School of } \\
\text { Medicine at } \\
\text { ECU_Professor } \\
\text { of Surgery and } \\
\text { Physiology }\end{array}$ & None & None & None & None & $\begin{array}{l}\text { Edwards } \\
\quad \text { Lifesciences }\end{array}$ & None \\
\hline Mario J. Garcia & $\begin{array}{l}\text { Content Reviewer- } \\
\text { ACCF Task Force } \\
\text { on Clinical Expert } \\
\text { Consensus } \\
\text { Documents }\end{array}$ & $\begin{array}{l}\text { Montefiore Medical } \\
\text { Center-Albert } \\
\text { Einstein College } \\
\text { of Medicine- } \\
\text { Chief, Division of } \\
\text { Cardiology }\end{array}$ & MD Imaging & None & None & None & Medtronic $\dagger$ & None \\
\hline Federico Gentile & $\begin{array}{l}\text { Content Reviewer- } \\
\text { ACCF Task Force } \\
\text { on Clinical Expert } \\
\text { Consensus } \\
\text { Documents }\end{array}$ & $\begin{array}{c}\text { Centro Medico } \\
\text { Diagnostico }\end{array}$ & None & None & None & None & None & None \\
\hline $\begin{array}{l}\text { Leonard N. Girardi, } \\
\text { MD }\end{array}$ & $\begin{array}{l}\text { Official Reviewer- } \\
\text { AATS }\end{array}$ & $\begin{array}{l}\text { New York- } \\
\text { Presbyterian/ } \\
\text { Weill Cornell } \\
\text { Medical College }\end{array}$ & None & None & None & None & None & None \\
\hline
\end{tabular}




\begin{tabular}{|c|c|c|c|c|c|c|c|c|}
\hline Peer reviewer & Representation & Employment & Consultant & $\begin{array}{c}\text { Speaker's } \\
\text { bureau }\end{array}$ & $\begin{array}{c}\text { Ownership/ } \\
\text { partnership/ } \\
\text { principal }\end{array}$ & Personal research & $\begin{array}{c}\text { Institutional, } \\
\text { organizational, or } \\
\text { other financial } \\
\text { benefit }\end{array}$ & Expert witness \\
\hline Steve Goldberg & $\begin{array}{l}\text { Official Reviewer- } \\
\text { SCAI }\end{array}$ & $\begin{array}{l}\text { University of } \\
\text { Washington } \\
\text { Medical Center }\end{array}$ & AGA Medical & None & None & None & $\begin{array}{l}\text { Amplatzer Division } \\
\text { of St. Jude } \\
\text { Medical }\end{array}$ & $\begin{array}{l}\text { Plaintiff, patent } \\
\quad \text { litigation, } 2010\end{array}$ \\
\hline Frederick L. Grover & $\begin{array}{l}\text { Content Reviewer- } \\
\text { ACCF Surgeon } \\
\text { Scientific Council }\end{array}$ & $\begin{array}{l}\text { University of } \\
\text { Colorado } \\
\text { Department of } \\
\text { Surgery- } \\
\text { Professor and } \\
\text { Chair }\end{array}$ & None & None & None & None & None & None \\
\hline Robert Guyton & $\begin{array}{l}\text { Content Reviewer- } \\
\text { ACC Surgeon } \\
\text { Scientific Council }\end{array}$ & $\begin{array}{l}\text { Emory Clinic, } \\
\text { Inc.-Professor } \\
\text { and Chief, } \\
\text { Division of } \\
\text { Cardiothoracic } \\
\text { Surgery }\end{array}$ & None & None & None & None & None & $\begin{array}{l}\text { Defendant, cardiac } \\
\text { surgery, } 2011\end{array}$ \\
\hline Jonathan Halperin & $\begin{array}{l}\text { Content Reviewer- } \\
\text { ACCF/AHA/ACP } \\
\text { Task Force on } \\
\text { Clinical } \\
\text { Competence and } \\
\text { Training }\end{array}$ & $\begin{array}{l}\text { Mount Sinai } \\
\text { Medical Center- } \\
\text { Professor of } \\
\text { Medicine }\end{array}$ & $\begin{array}{l}\text { Biotronix, Inc.* } \\
\text { Edwards } \\
\quad \text { Lifesciences } \\
\text { Johnson \& Johnson } \\
\text { Ortho-McNeil/ } \\
\text { Janssen } \\
\text { Pharmaceuticals }\end{array}$ & None & None & None & None & None \\
\hline Howard Herrmann & $\begin{array}{l}\text { Official Reviewer- } \\
\text { SCAI }\end{array}$ & $\begin{array}{l}\text { University of } \\
\text { Pennsylvania } \\
\text { Medical Center }\end{array}$ & $\begin{array}{l}\text { W.L. Gore* } \\
\text { St. Jude Medical }\end{array}$ & None & $\begin{array}{l}\text { Micro } \\
\quad \text { Interventional } \dagger\end{array}$ & $\begin{array}{l}\text { Edward } \\
\quad \text { Lifesciences* } \\
\text { W.L. Gore }\end{array}$ & None & None \\
\hline Joerg Herrmann & $\begin{array}{l}\text { Content Reviewer- } \\
\text { ACCF } \\
\text { Interventional } \\
\text { Scientific Council }\end{array}$ & Mayo Clinic & None & None & None & None & None & None \\
\hline David R. Holmes, Jr & $\begin{array}{l}\text { ACCF/AATS/SCAI/ } \\
\text { STS TAVR } \\
\text { Expert Consensus } \\
\text { Document } \\
\text { Writing } \\
\text { Committee }\end{array}$ & $\begin{array}{l}\text { Mayo Clinic- } \\
\text { Consultant, CV } \\
\text { Diseases }\end{array}$ & None & None & None & None & None & None \\
\hline
\end{tabular}




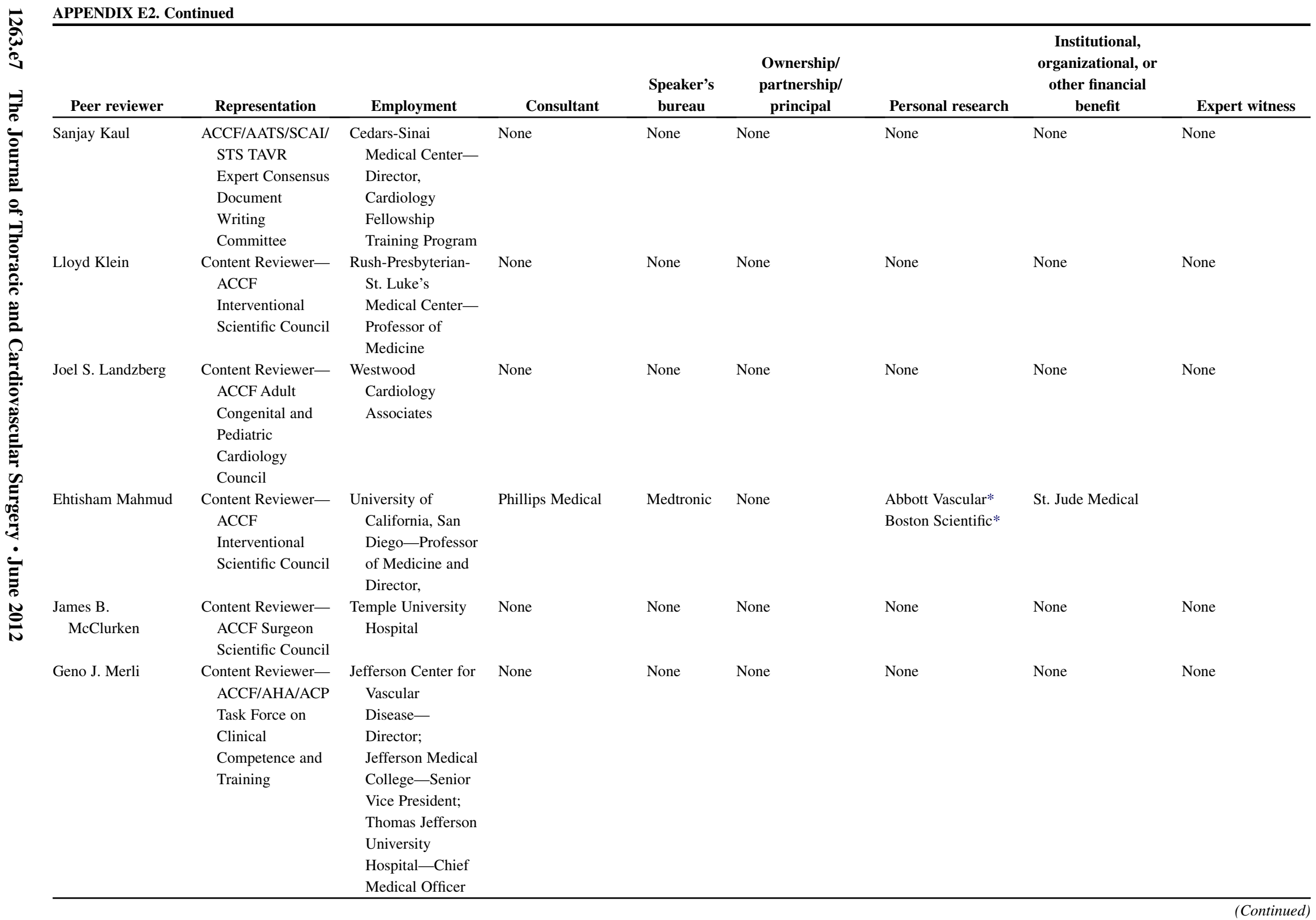




\begin{tabular}{|c|c|c|c|c|c|c|c|c|}
\hline Peer reviewer & Representation & Employment & Consultant & bureau & principal & Personal research & benefit & Expert witness \\
\hline Issam Moussa & $\begin{array}{l}\text { Content Reviewer- } \\
\text { ACCF } \\
\text { Interventional } \\
\text { Scientific Council }\end{array}$ & $\begin{array}{l}\text { Mayo Clinic- } \\
\text { Chair, Division of } \\
\text { CV Diseases }\end{array}$ & None & None & None & None & None & None \\
\hline Brent J. Muhlestein & $\begin{array}{l}\text { Content Reviewer- } \\
\text { ACCF/AHA/ACP } \\
\text { Task Force on } \\
\text { Clinical } \\
\text { Competence and } \\
\text { Training }\end{array}$ & $\begin{array}{l}\text { Intermountain } \\
\text { Medical Center, } \\
\text { Cardiology } \\
\text { Department- } \\
\text { Professor of } \\
\text { Medicine }\end{array}$ & None & None & None & None & None & $\begin{array}{l}\text { Defendant, cardiac } \\
\text { catheterization, } \\
2011\end{array}$ \\
\hline Srihari Naidu & $\begin{array}{l}\text { Content Reviewer- } \\
\text { ACCF } \\
\text { Interventional } \\
\text { Scientific Council }\end{array}$ & $\begin{array}{l}\text { Winthrop University } \\
\text { Hospital—- } \\
\text { Director, Cardiac } \\
\text { Cath Lab }\end{array}$ & Abbott Vascular & None & None & None & None & None \\
\hline Hani Najm & $\begin{array}{c}\text { Content Reviewer- } \\
\text { ACCF Surgeon } \\
\text { Scientific Council }\end{array}$ & $\begin{array}{l}\text { National Guard } \\
\text { Health Affairs- } \\
\text { President, Saudi } \\
\text { Heart Association }\end{array}$ & None & None & None & None & None & None \\
\hline Jennifer S. Nelson & $\begin{array}{l}\text { Official Reviewer- } \\
\text { STS }\end{array}$ & $\begin{array}{l}\text { University of } \\
\text { Michigan }\end{array}$ & None & None & None & None & None & None \\
\hline Ileana Piña & $\begin{array}{l}\text { Content Reviewer- } \\
\text { ACCF/AHA/ACP } \\
\text { Task Force on } \\
\text { Clinical } \\
\text { Competence and } \\
\text { Training }\end{array}$ & $\begin{array}{l}\text { Montefiore Medical } \\
\text { Center- } \\
\text { Professor of } \\
\text { Medicine and } \\
\text { Epidemiology } \\
\text { and Population } \\
\text { Health }\end{array}$ & GE HealthCare & None & None & None & None & None \\
\hline Stephen Ramee & $\begin{array}{l}\text { Official Reviewer- } \\
\text { ACCF Board of } \\
\text { Governors }\end{array}$ & $\begin{array}{l}\text { Ochsner Clinic } \\
\text { Foundation- } \\
\text { Director, Cardiac } \\
\text { Catheterization }\end{array}$ & None & None & Boston Scientific* & $\begin{array}{l}\text { Abbott } \dagger \\
\text { Boston Scientific } \dagger \\
\text { Edwards } \\
\text { Lifesciences } \dagger \\
\text { Medtronic } \dagger\end{array}$ & None & None \\
\hline
\end{tabular}




\begin{tabular}{|c|c|c|c|c|c|c|c|c|}
\hline Peer reviewer & Representation & Employment & Consultant & $\begin{array}{c}\text { Speaker's } \\
\text { bureau }\end{array}$ & $\begin{array}{c}\text { Ownership/ } \\
\text { partnership/ } \\
\text { principal }\end{array}$ & Personal research & $\begin{array}{c}\text { Institutional, } \\
\text { organizational, or } \\
\text { other financial } \\
\text { benefit }\end{array}$ & Expert witness \\
\hline Richard Smalling & Content Reviewer- & University of Texas & AGA Medical & None & None & AGA Medical & AGA Medical* & None \\
\hline & ACCF Surgeon & Medical & & & & Cordis & Cordis* & \\
\hline & Scientific Council & School—Jay & & & & E-valve* & & \\
\hline & & Brent Sterling & & & & & & \\
\hline & & Professor of & & & & & & \\
\hline & & Cardiovascular & & & & & & \\
\hline & & Medicine & & & & & & \\
\hline Wilson Y. Szeto & $\begin{array}{l}\text { Official Reviewer- } \\
\text { STS }\end{array}$ & $\begin{array}{l}\text { University of } \\
\text { Pennsylvania }\end{array}$ & None & None & None & $\begin{array}{l}\text { Edwards } \\
\quad \text { Lifesciences }\end{array}$ & None & None \\
\hline Vinod H. Thourani & Official Reviewer- & Emory University & Edwards & None & None & None & None & None \\
\hline & STS & & Lifesciences & & & & & \\
\hline & & & Sorin Medical & & & & & \\
\hline & & & St. Jude Medical & & & & & \\
\hline $\begin{array}{l}\text { This table represents tl } \\
\text { publication. A person i } \\
\text { entity; or if funds rece } \\
\text { Relationships that exis } \\
\text { According to the ACC } \\
\text { entity (with whom the } \\
\text { a reasonable potential } \\
\text { Foundation; SCAI, Soc }\end{array}$ & $\begin{array}{l}\text { elationships of reviewers } \\
\text { eemed to have a significan } \\
d \text { by the person from the } \\
\text { ith no financial benefit are } \\
\text { person has a relevant rela } \\
\text { ationship exists) makes a } \\
\text { financial, professional or } \\
\text { v for Cardiovascular Ang }\end{array}$ & $\begin{array}{l}\text { ith industry and other ent } \\
\text { nterest in a business if the } \\
\text { siness entity exceed } 5 \% \\
\text { lso included for the purp } \\
\text { onship IF: (a) The relatio } \\
\text { ag, drug class, or device } \\
\text { her personal gain or loss }\end{array}$ & $\begin{array}{l}\text { es that were disclosec } \\
\text { terest represents own } \\
\text { the person's gross in } \\
\text { e of transparency. Re } \\
\text { hip or interest relates } \\
\text { Iressed in the docume } \\
\text { a result of the issues }\end{array}$ & $\begin{array}{l}\text { e time of peer } \\
\text { of } \geq 5 \% \text { of th } \\
\text { for the previou } \\
\text { ships in this tat } \\
\text { same or simila } \\
\text { makes a comp } \\
\text { nt addressed in }\end{array}$ & $\begin{array}{l}\text { View and determined } t \\
\text { oting stock or share of } \\
\text { year. A relationship i } \\
\text { are modest unless ot } \\
\text { ubject matter, intellec } \\
\text { ing drug or device add } \\
\text { ne document. AATS, A }\end{array}$ & $\begin{array}{l}\text { relevant. It does not neces } \\
\text { usiness entity, or ownersh } \\
\text { sidered to be modest if it } \\
\text { se noted. Names are liste } \\
\text { roperty or asset, topic, or } \\
\text { d in the document; or (c) } \\
\text { can Association for Thor } \\
\text { ancial benefit. }\end{array}$ & $\begin{array}{l}\text { arily reflect relationships } \\
\text { of } \geq \$ 10,000 \text { of the fair } n \\
\text { less than significant und } \\
\text { in alphabetical order with } \\
\text { sue addressed in the docu } \\
\text { he person or a member of } \\
\text { ic Surgery; } A C C F, \text { Amer }\end{array}$ & $\begin{array}{l}\text { th industry at the time of } \\
\text { rket value of the business } \\
\text { the preceding definition. } \\
\text { each category of review. } \\
\text { ent; or (b) The company/ } \\
\text { e person's household has } \\
\text { in College of Cardiology }\end{array}$ \\
\hline
\end{tabular}

